\title{
Determinants of neonatal IgE level: parity, maternal age, birth season and perinatal essential fatty acid status in infants of atopic mothers
}

Citation for published version (APA):

van Gool, C. J. A. W., Thijs, C. T. M., Dagnelie, P. C., Henquet, C. E. C., van Houwelingen, A. C., Schrander, J. J. P., Menheere, P. P., \& van den Brandt, P. A. (2004). Determinants of neonatal lgE level: parity, maternal age, birth season and perinatal essential fatty acid status in infants of atopic mothers. Allergy, 59(9), 961-968. https://doi.org/10.1111/j.1398-9995.2004.00528.x

Document status and date:

Published: 01/01/2004

DOI:

10.1111/j.1398-9995.2004.00528.x

Document Version:

Publisher's PDF, also known as Version of record

Please check the document version of this publication:

- A submitted manuscript is the version of the article upon submission and before peer-review. There can be important differences between the submitted version and the official published version of record.

People interested in the research are advised to contact the author for the final version of the publication, or visit the DOI to the publisher's website.

- The final author version and the galley proof are versions of the publication after peer review.

- The final published version features the final layout of the paper including the volume, issue and page numbers.

Link to publication

\footnotetext{
General rights rights.

- You may freely distribute the URL identifying the publication in the public portal. please follow below link for the End User Agreement:

www.umlib.nl/taverne-license

Take down policy

If you believe that this document breaches copyright please contact us at:

repository@maastrichtuniversity.nl

providing details and we will investigate your claim.
}

Copyright and moral rights for the publications made accessible in the public portal are retained by the authors and/or other copyright owners and it is a condition of accessing publications that users recognise and abide by the legal requirements associated with these

- Users may download and print one copy of any publication from the public portal for the purpose of private study or research.

- You may not further distribute the material or use it for any profit-making activity or commercial gain

If the publication is distributed under the terms of Article $25 \mathrm{fa}$ of the Dutch Copyright Act, indicated by the "Taverne" license above, 


\section{Determinants of neonatal IgE level: parity, maternal age, birth season and perinatal essential fatty acid status in infants of atopic mothers}

\begin{abstract}
Objective: The hygiene hypothesis suggests that the protective 'siblings effect' against atopic diseases such as atopic dermatitis, allergic asthma and hay fever is a result of recurrent infections during early childhood. A recent study and review have indicated that this protective effect may already arise in utero. Lower n-3 essential fatty acid (EFA) status is associated with increased parity, and EFA status has also been related to atopy. The present study confirms the negative association between parity and neonatal immunoglobulin $\mathrm{E}$ (IgE) levels and further unravel the role of perinatal EFA status.

Methodology: In a prospective cohort study in 184 atopic mothers and their neonates, we simultaneously measured serum total IgE and EFA levels in plasma phospholipids, both in the mother at 34-36 weeks of gestation and in the neonate at the age of 1 week. Linear regression analysis was used to estimate the effect of parity on maternal and neonatal IgE and EFA status, and the independent effects of parity and EFA status on IgE, controlling for confounding factors such as maternal age and birth season.

Results: Parity was associated with lower neonatal IgE level $(P<0.01)$, as well as with lower docosahexanoic acid (DHA, 22:6n-3) status of the mother $(P=0.01)$ but not of the neonate $(P>0.69)$. In the multivariate analysis, higher parity, higher maternal IgE, lower maternal age and birth in the first 3 months of the year were independently associated with neonatal IgE level. No association was detected between maternal or neonatal EFA status and neonatal IgE.

Conclusions: As neonatal total serum IgE is predictive of later atopy, our results support the hypothesis that the sibling effect in atopy is already being programmed in utero. Our data also confirm earlier findings that DHA status is lower in multiparous women, but this did not confound the relation between parity and neonatal IgE.
\end{abstract}

\author{
C. J. A. W. van Gool', C. Thijs', \\ P. C. Dagnelie', C. J. M. Henquet?, \\ A. C. van Houwelingen ${ }^{3}$, \\ J. Schrander', P. P. C. A. Menheere', \\ P. A. van den Brandt' \\ 'Department of Epiderniology, Nutrition and \\ Toxicology Research Institute Maastricht (NUTRIM). \\ Maastricht University: ${ }^{2}$ Department of Dermatology. \\ Academic Hospital Maastricht; ${ }^{3}$ Department of \\ Human Biology, Nutrition and Toxicology Research \\ Institute Maastricht (NUTRIM), Maastricht \\ University: ${ }^{4}$ Department of Paediatrics, Academic \\ Hospital Maastricht: ${ }^{5}$ Department of Clinical \\ Chemistry, Academic Hospital Maastricht, \\ Maastricht, The Netherlands
}

Key words: atopic dermatitis; atopy; essential; fatty
acids.
C. J. A. W. van Gool
Department of Epidemiology
Maastricht University
PO Box 616
NL-6200 MD Maastricht
The Netherlands
Accepted for publication 28 January 2004

Key words: atopic dermatitis; atopy; essential; fatty

C. J. A. W. van Gool

Department of Epidemiology

PO Box 616

Accepted for publication 28 January 2004
The prevalence of atopic eczema in the Western world has increased two- to threefold over the last three decades (1). Several theories have been put forward to explain this increase, most of them focusing on early life events. One example of such theories is the hygiene hypothesis. This was first postulated by Strachan (2), who found the prevalence of hay fever and atopic dermatitis (AD) to be inversely related to the number of older siblings. Similar associations have been reported since $(1,3,4)$. This effect has been tentatively explained by the greater chances of cross-infection from older siblings in large families, which may have an important protective role in the expression of atopy: the so-called sibling effect. The age of infection might be crucial, as it has also been found that the rise of AD in the first year of life is negatively associated with the number of children in the household, the so-called sibling-effect (5).
A recent study by Karmaus et al. (6) suggested that cord blood immunoglobulin E (IgE) levels decrease with increasing birth order. The literature is ambivalent about whether cord blood IgE is predictive for the later development of atopy or not. However, the concentration of total IgE in umbilical cord blood was found in several studies to be positively associated with later development of atopy $(7,8,36,37)$, the sibling effect may have its origin (at least partly) in utero. If this hypothesis were correct, neonatal IgE would be expected to be negatively associated with increasing parity.

Maternal essential fatty acid (EFA) status is also influenced by parity, and has also been implicated in the development of atopy. It has long been recognized that atopic and nonatopic individuals differ with respect to the proportions of various polyunsaturated fatty acids in their blood $(9,38,39)$. Studies in adults have found 
van Gool et al.

increased levels of linoleic acid (18:3n-6, LA) and alpha-linolenic acid (18:3n-3, ALA), and decreased levels of n-6 and n-3 long chain polyenes (LCPs) in blood, adipose tissue and human milk of atopic individuals $(10-13)$. The LCPs, n-6 and n-3 derivatives of LA and ALA, respectively, are the precursors of inflammatory mediators such as prostaglandins and leukotrienes and are embedded in cell membranes, where they play a role in membrane fluidity and signal transduction. An earlier study showed that low n-6 LCP levels in cord blood precede the development of atopy in infants (14), which might suggest a causal relationship and points to the importance of neonatal EFA status.

Neonatal EFA status depends on intrauterine EFA supply. Parity would, however, be expected to increase the risk of atopic disease if maternal EFA status is depleted by earlier pregnancies. Increasing parity has indeed shown to be associated with relative n-3 LCP depletion, most notably of docosahexanoic acid (DHA) as a marker of n-3 EFA status; maternal DHA status has been shown to decrease during a normal pregnancy (15) and to decrease further with increasing parity (16).

We studied the effect of parity on neonatal total serum IgE levels and on perinatal DHA status, as well as their inter-independence, as part of an ongoing study of the relationship between the development of atopy and EFAs. We also explored whether DHA or other perinatal EFAs are an intermediate or confounding factor in the relationship between parity and neonatal IgE.

\section{Materials and methods}

\section{Study design and population}

This study was initially designed to determine (1) the relationship in a 64 infants of breastfed neonates between the mothers' prepartum EFA status, EFA in breast milk, and the children's EFA status on the one hand and the development of atopic disease at the age of 1 year on the other; and (2) whether supplementing bottle-fed neonates with gamma-linolenic acid (GLA, 18:3n-6) from 1 week of age until 6 months prevents atopic disease at the age of 1 year (118 infants) (34). Formula feeding meant exclusive formula feeding after 1 week of life and exclusive breastfeeding meant no formula at all in the first 4 weeks of life.

Subjects eligible for the study were atopic pregnant women and their neonates. They were recruited between October 1997 and April 2000 by midwives and via advertisements in local newspapers in the provinces of Limburg and Noord-Brabant (the Netherlands). The atopic status of both parents was assessed using a validated telephone questionnaire. Inclusion criteria for atopic mothers were: a history of allergic asthma or allergic rhinoconjunctivitis (in relation to aeroallergen exposure), or a history of $\mathrm{AD}$, and/or a history of positive allergy test, and/or improvement of asthma or rhinoconjunctivitis complaints by antihistamine drugs. Noninclusion criteria were: diabetes treated with medication and/or a prescribed diet, (pre-)-eclampsia and metabolic diseases.

Neonates were born between December 1997 and May 2000 Inclusion criteria for the neonates were: gestational age of at least 38 weeks, birth weight $>2500 \mathrm{~g}$ and an uncomplicated birth and neonatal period.

\section{Sampling and laboratory analyses}

Blood was collected from the mothers by venepuncture of the median cubital vein at 34-36 weeks of gestation, and from the infants at the age of about 1 week (5-8 days) by heel prick. Blood was collected in EDTA-containing tubes (Becton Dickinson, Orangeburg, SC, USA) and serum separator tubes (Sherwood-Davis \& Geck, St Louis, MO, USA). The samples were transported on ice/water mixture and, within $24 \mathrm{~h}$ after collection, centrifuged for $10 \mathrm{~min}\left(3000 \mathrm{~g}\right.$ at $\left.4^{\circ} \mathrm{C}\right)$, and stored at $-20^{\circ} \mathrm{C}$ (serum) or $-50^{\circ} \mathrm{C}$ (plasma) under nitrogen until analysis. If an insufficient amount of venous blood was acquired from the mother, finger prick blood was collected on blotting paper for total serum IgE analysis. Neonatal blood sampling always preceded the start of the GLA supplementation.

Fatty acids (FAs) in plasma phospholipids were analyzed as previously described (17). Briefly, lipid extracts were prepared from plasma samples, and phospholipid (PL) fractions separated using aminopropyl-bonded phase columns (18). PLs were hydrolyzed and FAs transmethylated with boron trifluoride (Sigma, St Louis, MO, USA) in methanol. The composition of the FA methyl esters obtained was determined by capillary gas chromatography using a polar capillary column (CPSil 88; Chrompack, Middelburg, the Netherlands), with helium as the carrier gas. The amount of each FA was quantified by adding an internal standard (dinonadecanoyl [19:0]-phosphatidylcholine; Sigma). Results are reported as weight percentage (wt\%) of total FAs, computed as previously described (15).

Specific IgE tests against a battery of food allergens (Fx5), aeroallergens (Phadiatop, cut-off point $0.35 \mathrm{kU} / \mathrm{l}$ ) and a test for total serum IgE (detection limit $0.02 \mathrm{kU} / \mathrm{l}$ ) in the mother were performed in serum using the Pharmacia Unicap system (Pharmacia Upjohn, Uppsala, Sweden) as described elsewhere (19). Total IgE (detection limit $0.15 \mathrm{kU} / \mathrm{l}$ ) in the neonates was determined at the Central Laboratory of the blood-transfusion services in Amsterdam. This was done in eluded blood spot material in a sandwich assay, according to Aalberse et al. (20), with minor modifications: a mixture of anti-human IgE monoclonal antibodies was coupled to Sepharose 4B to catch IgE, and Sepharose-bound $\mathrm{IgE}$ was detected by means of radio-labeled antibodies against human $\operatorname{IgE}$, raised in sheep.

\section{Statistical analysis}

We evaluated three hypotheses: (1) parity influences maternal and neonatal total serum IgE, (2) parity influences DHA depletion in the mother during pregnancy and (3) the possible role of DHA as a confounder or as an intermediate factor in the relationship between parity and neonatal total serum IgE. In an explorative analysis, we assessed whether other EFAs were associated with neonatal IgE. The significant $P$-value used in the analysis was $P<0.05$. If total serum IgE was nondetectable the value 0.01 was assigned for the linear regression analyses.

The main outcome variables for the first hypothesis were total serum IgE levels of mothers at 34-36 weeks of gestation (maternal $\mathrm{IgE}$ ) and of neonates at $\mathrm{I}$ week of age (neonatal $\mathrm{IgE}$ ). Total serum IgE was not normally distributed and was therefore transformed to its natural logarithm (ln IgE). Linear regression analysis, as singlestep analysis, was applied to estimate the strength of the association between the outcome variables and parity, controlling for possible confounding factors [maternal age, season of birth, smoking during pregnancy and, in the case of the neonates, gender, maternal $\mathrm{IgE}$, atopy of the father and type of feeding (formula or breast milk)].

The main outcome variables for the second hypothesis were maternal and neonatal DHA levels. Linear regression analysis, as 
single-step analysis, was applied to estimate the strength of the association between these outcome variables and parity.

The main outcome variable for the third hypothesis was neonatal total serum IgE (In IgE). The possible role of DHA as a confounder or as an intermediate factor in the relationship between parity and neonatal total serum IgE was assessed by applying linear regression analysis to estimate the strength of the association between the outcome variables and parity, controlling for DHA in addition to the other possible confounding factors.

The explorative analysis assessed whether other EFAs were associated with neonatal total serum IgE, controlling for other covariables. We tested for influential outliers by calculating Cooks distances. Cooks distance $<1$ was considered to be normal. The EFAs included in the analyses were LA (18:2n-3), GLA (18:3n-6), dihomo-gamma-linolenic acid (DGLA, 20:3n-6), arachidonic acid (AA, 22:4n-6), adrenic acid (22:4n-6), Osbond acid (22:5n-6), ALA (18:3n-3), 18:4n-3, eicosapentaenoic acid (EPA, 20:5n-3) and docosapentanoic acid (DPA, 22:5n-3). To facilitate the interpretation of the regression coefficients when comparing the association of each EFA with IgE, we computed standardized regression coefficients (=regression coefficient $\times[S D(x) / S D(y)]$, where $\operatorname{SD}(x)$ is the standard deviation of the EFA and $\mathrm{SD}(\mathrm{y})$ is the standard deviation of $\ln \operatorname{IgE}$ in the study population) (21).

Statistical analyses were performed by means of the SPSS for Windows program (version 10.0; SPSS, Inc., Chicago, IL, USA).

\section{Results}

\section{Study population}

One hundred and eighty-two mothers with their neonates were included in the study. As shown in Table 1, almost half of the mothers were primipara $(47 \%)$, while $37 \%$ of the mothers had had one previous infant, $13 \%$ had had two previous infants and 3\% had had three previous infants. Sixty-four neonates were exclusively breastfed and 118 neonates were formula-fed in the first week. Seventy-nine percent of the mothers had a positive inhalant allergen test (Phadiatop) and 14\% had a positive food allergen test (Fx5) (Table 1).

\section{Total serum $\lg E$}

Increasing parity was associated with decreasing total serum $\operatorname{IgE}$ in the neonates $(P=0.006)$ (Table 2$)$. The regression coefficient of -0.57 can be interpreted as follows: with each subsequent child, the neonatal IgE level increases by a factor $\exp (-0.57)=0.57(95 \%$ confidence interval $0.40-0.85$ ), i.e. the IgE level is almost halved. There was also a statistically significant effect of

Table 1. Characteristics of mothers and neonates

\begin{tabular}{|c|c|c|c|c|}
\hline & \multicolumn{3}{|c|}{ Parity, $n(\%)$} & \multirow[b]{2}{*}{ Total } \\
\hline & 1 & 2 & $>3$ & \\
\hline$n$ & 85 & 68 & $29^{*}$ & 182 \\
\hline $\begin{array}{l}\text { Maternal total serum lgE kU/l, } \\
\text { median (SD) }\end{array}$ & $178(728)$ & $92.5(451)$ & $55(191)$ & $100(578)$ \\
\hline $50-99 \mathrm{kU} / \mathrm{l}, n$ & 36 & 36 & 19 & 91 \\
\hline $100-199 \mathrm{kU} / \mathrm{l}, n$ & 15 & 11 & 3 & 29 \\
\hline$>200 \mathrm{kU} / \mathrm{l}, n$ & 34 & 21 & 7 & 62 \\
\hline Maternal positive Phadiatop $\ddagger, n(\%)$ & $64(80)$ & $53(80)$ & $20(77)$ & $137(79)$ \\
\hline Maternal positive $F \times 5^{*} \ddagger, n(\%)$ & $16(20)$ & $8(12)$ & $2(7)$ & $26(15)$ \\
\hline Smoking in pregnancy by mother, $n(\%)$ & $18(21)$ & $8(12)$ & $5(17)$ & $31(17)$ \\
\hline Paternal positive history of atopy, $n(\%)$ & $30(36)$ & $26(38)$ & $10(34)$ & $66(36)$ \\
\hline Age mother at delivery, mean (SD) & $29(4)$ & $32(3)$ & $34(3)$ & $31.35(3.85)$ \\
\hline Breastfeeding, $n(\%)$ & $28(33)$ & $27(40)$ & $9(31)$ & $64(35)$ \\
\hline \multicolumn{5}{|l|}{ Season of birth neonate } \\
\hline First (January, February, March), $n(\%)$ & $20(24)$ & $14(21)$ & $6(21)$ & $40(22)$ \\
\hline Second (April, May, June), $n(\%)$ & $17(20)$ & $21(31)$ & $11(38)$ & $49(27)$ \\
\hline Third (July, August, September), $n(\%)$ & $34(40)$ & $22(32)$ & $8(28)$ & $64(35)$ \\
\hline Fourth (October, November, & $14(16)$ & $11(16)$ & $4(14)$ & $29(16)$ \\
\hline \multicolumn{5}{|l|}{ December), $n(\%)$} \\
\hline Boys, $n(\%)$ & $36(42)$ & $28(41)$ & $22(75)$ & $86(47)$ \\
\hline Infant IgE at 1 week $\mathrm{kU} / \mathrm{I}$, median $(S D) \S$ & $0.30(3.9)$ & $0.30(2.9)$ & $0.21(0.5)$ & $0.30(3.26)$ \\
\hline Nondetectable, $n$ & 34 & 24 & 14 & 72 \\
\hline $0.15-0.5, n$ & 15 & 20 & 9 & 44 \\
\hline $0.5-18, n$ & 32 & 24 & 6 & 62 \\
\hline
\end{tabular}

$n$, number of participants; SD, standard deviation; Phadiatop, specific inhalant allergy test (positive if $>0.35 \mathrm{kU} / \mathrm{ll}$; $\mathrm{F} \times 5$, food allergy test directed against cow's milk, egg-white, soy, shell fish, nuts, wheat.

* 24 mothers had parity 3 , five had parity 4.

+ Number of participants with positive specific test according to total serum lgE level.

$\ddagger$ Missing specific $\lg E$ in mothers $n=9$ (parity $1, n=5$; parity $2, n=2$; parity $>3, n=2$ )

$\S$ Missing total lgE in infants, $n=4$. 
van Gool et al.

Table 2. IgE as natural logarithm (In) in total serum of mothers at 34-36 weeks of gestation and in neonates at 1 week of age, in relation to parity and other determinants

\begin{tabular}{|c|c|c|c|c|c|c|}
\hline & \multicolumn{3}{|c|}{ Mother $34-36$ weeks of gestation $(n=182)$} & \multicolumn{3}{|c|}{ Neonate at 1 week of age $\left(n=178^{*}\right)$} \\
\hline & Regression coefficient & Standard error & $P$-value & Regression coefficient & Standard error & $P$-value \\
\hline Parity $(1,2,3,4)$ & -0.23 & 0.17 & 0.16 & -0.57 & 0.21 & 0.006 \\
\hline Age mother at delivery (years) & -0.06 & 0.04 & 0.08 & 0.10 & 0.04 & 0.02 \\
\hline In $\lg E$ mother (In $\mathrm{kU} / \mathrm{l})$ & & & & 0.18 & 0.09 & 0.06 \\
\hline Smoking during pregnancy $(0=$ no, $7=$ yes $)$ & -0.42 & 0.31 & 0.17 & -0.50 & 0.40 & 0.21 \\
\hline \multicolumn{7}{|l|}{ Season of birth } \\
\hline First (January, February, March) & 0.15 & 0.31 & 0.64 & -1.68 & 0.46 & 0.001 \\
\hline Second (April, May, June) & 0.72 & 0.32 & 0.02 & -0.67 & 0.46 & 0.15 \\
\hline Third (July, August, September) & 0.16 & 0.31 & 0.17 & -0.42 & 0.42 & 0.33 \\
\hline Fourth (October, November, December) & Reference & & & Reference & & \\
\hline Atopy father $(0=$ no, $1=$ yes $)$ & & & & 0.35 & 0.29 & 0.23 \\
\hline Gender $(1=$ boy, $2=$ giri $)$ & & & & -0.21 & 0.29 & 0.46 \\
\hline Type of feeding ( $0=$ formula, $1=$ breast milk $)$ & & & & & 0.31 & 0.68 \\
\hline
\end{tabular}

Results from multivariate linear regression analysis, all variables in the table being included in the model.

* Five missing total serum lgE.

the age of the mother, suggesting that age is positively related to higher serum IgE levels in the children at the age of 1 week. Maternal IgE level showed no association with parity, but a borderline significant association with neonatal IgE.

\section{Role of essential fatty acid status}

Maternal DHA status decreased with parity [regression coefficient $=-0.33, \quad(\mathrm{SE}=0.12), \quad P=0.007] . \quad$ Of the other EFAs, only EPA also decreased with parity [ $-0.08(0.03), P=0.02]$. No effects of parity on DHA or other EFAs were found in the neonates at 1 week of age. When maternal DHA was included in the multivariate models of Table 2, the regression coefficients of the association between parity and maternal or neonatal IgE hardly changed. This was also true when all other maternal or neonatal EFAs were included. Maternal DHA showed no statistically significant association with maternal IgE on its own [regression coefficient $=0.15$ (SE $=0.12), P=0.18]$, or with neonatal $\operatorname{IgE}[0.09(0.13)$, $P=0.49]$.

In the explorative analyses of individual FAs and neonatal IgE we found one influential outlier in the regression analysis of $22: 4 n-6$ in maternal blood (Cook's distance 3.2). We omitted this outlier from this analysis (Table 3). The explorative analyses found a negative association between maternal LA levels and neonatal IgE levels $(P=0.04)$ (Table 3). After correction for covariables, this association remained $(P=0.03)$ and AA was positively associated with neonatal serum IgE levels. Neonatal ALA levels were negatively associated with neonatal $\operatorname{IgE}(P=0.03)$, while 18:4n-3 and DPA was positively associated $(P$-values 0.02 and 0.03 , respectively). After correction for covariables, the association of ALA, 18:4n-3 and DPA with neonatal IgE remained statistically signifcant ( $P$-values $0.01,0.049$ and 0.04 , respectively) and
EPA became negatively associated with neonatal $\operatorname{IgE}$ levels $(P=0.047)$

\section{Discussion}

The first aim of the present study was to evaluate the association between parity and neonatal IgE levels. Our results confirm Karmaus findings (6) that parity is associated with lower IgE levels in neonatal serum. Other determinants of neonatal IgE level were found to be higher maternal IgE, higher maternal age and birth outside the first 3 months of the year.

Our second hypothesis concerned the association between parity and maternal and neonatal EFA status, especially DHA. Other studies have shown that parity is associated with lower maternal DHA status and also with neonatal EFA status as measured in cord plasma and umbilical vein and artery wall (16). Our data confirm that maternal DHA decreases with increasing parity, but neonatal DHA was unrelated to parity. There are several potential explanations for our findings. First, there may be mechanisms ensuring neonatal EFA status at the expense of maternal EFA status. Secondly, the neonates may be able to synthesize a sufficient amount of DHA from its precursors soon after birth and normalize a DHA deficit within 1 week. Current evidence is indecisive for these explanations $(22,23)$. Nonetheless, although we have found statistical relationships, causality cannot be inferred from this type of study.

Our third hypothesis was that DHA and other EFAs play a role in the relationship between parity and neonatal IgE levels. No relationship was found between maternal DHA and neonatal IgE levels. We assessed the role of maternal DHA in the relationship between parity and neonatal IgE by including maternal DHA in the multivariate analysis. As the relationship between parity and neonatal IgE did not change, we conclude that 
Table 3. Neonatal igE as natural logarithm (In) at 1 week of age, in relation to maternal phospholipid essential tatty acid (EFA) status at 34-36 weeks of gestation and neonatal phospholipid EFA status at 1 week of age and covariables

\begin{tabular}{|c|c|c|c|c|c|c|c|}
\hline & $\begin{array}{l}\text { Mean } w t \% \\
\text { (SD) }\end{array}$ & $\begin{array}{c}\text { Regression } \\
\text { coefficient, uncontrolled } \\
\text { for covariables (SE) }\end{array}$ & $\begin{array}{l}\text { Standardized } \\
\text { coefficient,uncontrolled } \\
\text { for covariables }\end{array}$ & $P$-value & $\begin{array}{l}\text { Regression coefficient, } \\
\text { controlled for } \\
\text { covariables (SE) }\end{array}$ & $\begin{array}{l}\text { Standardized } \\
\text { coefficient, controlled } \\
\text { for covariables }\end{array}$ & $P$-value \\
\hline \multicolumn{8}{|c|}{ Maternal phospholipid, EFAs ( $n=161$ ) } \\
\hline 18:2n-6, LA & $21.63(2.61)$ & $-0.116(0.057)$ & -0.162 & 0.04 & $-0.129(1.845)$ & -0.180 & 0.02 \\
\hline 18:3n-6, GLA & $0.04\{0.03\}$ & $4.143(5.364)$ & 0.062 & 0.44 & $4.236(5.311)$ & 0.063 & 0.42 \\
\hline 20:3n-6, DGLA & $3.53(0.70)$ & $-0.151(0.213)$ & -0.057 & 0.48 & $-0.166(0.211)$ & -0.062 & 0.43 \\
\hline $20: 4 n-6, A A$ & $8.22(1.49)$ & $0.172(0.099)$ & 0.137 & 0.09 & $0.212(0.097)$ & 0.169 & 0.03 \\
\hline $22: 4 n-6$, adrenic acid* & $0.36(0.07)$ & $2.747(2.024)$ & 0.108 & 0.17 & $4.015(1.978)$ & 0.158 & 0.04 \\
\hline 22:5n-6, Osbond acid & $0.45(0.16)$ & $0.722(0.937)$ & 0.062 & 0.44 & $0.749(0.956)$ & 0.063 & 0.43 \\
\hline $18: 3 n-3$, ALA & $0.25(0.09)$ & $-1.523(1.683)$ & -0.072 & 0.37 & $-1.237(1.702)$ & -0.059 & 0.47 \\
\hline $18: 4 n-3$ & $0.12(0.05)$ & $-2.597(3.030)$ & -0.068 & 0.39 & $-3.986(3.075)$ & -0.105 & 0.20 \\
\hline $20: 5 n-3, E P A$ & $0.34(0.28)$ & $0.959(0.535)$ & 0.142 & 0.08 & $0.539(0.539)$ & 0.080 & 0.32 \\
\hline $22: 5 n-3, \mathrm{DPA}$ & $0.55(0.13)$ & $1.413(1.179)$ & 0.096 & 0.23 & $1.088(1.198)$ & 0.072 & 0.37 \\
\hline 22:6n-3, DHA & $3.79(1.06)$ & $0.167(0.140)$ & 0.095 & 0.24 & $0.084(0.143)$ & 0.047 & 0.56 \\
\hline \multicolumn{8}{|c|}{ Neonatal phospholipid, EFAs $(n=178)$} \\
\hline 18:2n-6, LA & $16.57(2.41)$ & $-0.020(0.060)$ & -0.025 & 0.74 & $0.009(0.063)$ & 0.011 & 0.89 \\
\hline $18: 3 n-6$, GLA & $0.07(0.05)$ & $-4.220(3.148)$ & -0.101 & 0.18 & $-4.709\{3.051\}$ & -0.113 & 0.13 \\
\hline $20: 3 n-6$, DGLA & $2.67(0.72)$ & $0.141(0.202)$ & 0.053 & 0.49 & $-0.062(0.251)$ & -0.023 & 0.80 \\
\hline $20: 4 n-6, A A$ & $11.34(3.03)$ & $0.063(0.048)$ & 0.100 & 0.19 & $0.020(0.063)$ & 0.031 & 0.75 \\
\hline $22: 4 n-6$, adrenic acid & $0.37(0.12)$ & $1.580(1.248)$ & 0.096 & 0.21 & $1.410(1.324)$ & 0.085 & 0.29 \\
\hline $22: 5 n-6,0$ sbond acid & $0.34(0.21)$ & $-0.206(0.681)$ & -0.023 & 0.76 & $-0.632(0.653)$ & -0.071 & 0.33 \\
\hline $18: 3 n-3$, ALA & $0.11(0.08)$ & $-3.748(1.758)$ & -0.160 & 0.03 & $-4.747(2.110)$ & -0.203 & 0.03 \\
\hline $18: 4 n-3$ & $0.06\langle 0.04\}$ & $8.554(3.612)$ & 0.177 & 0.02 & $7.299(3.674)$ & 0.151 & 0.049 \\
\hline $20: 5 n-3$, EPA & $0.32(0.14)$ & $-1.227(1.004)$ & -0.093 & 0.22 & $-1.942(0.972)$ & -0.145 & 0.047 \\
\hline $22: 5 n-3$, DPA & $0.32(0.14)$ & $2.243(1.052)$ & 0.160 & 0.03 & $2.469(1.206)$ & 0.175 & 0.04 \\
\hline $22: 6 n-3$, DHA & $3.87(1.18)$ & $0.120(0.124)$ & 0.122 & 0.11 & $0.088(0.126)$ & 0.053 & 0.49 \\
\hline
\end{tabular}

Regression coefficients uncontrolled for covariables are between one particular EFA and neonatal In lgE. Regression coefficients controlled for covariables are between one particular EFA and neonatal In IgE, controlled for parity, age of mother at time of delivery, IgE of mother, smoking during pregnancy, season of birth, atopic status of the father, gender and type of feeding.

* One outlier exciuded.

maternal DHA is not a confounding or intermediate factor in this relationship. As this was also true when all EFAs were included in the model together, it is not likely that EFA status or any particular EFAs are confounding or intermediate factors.

The above relationships were studied in a hypothesisdriven approach. In a further analysis we explored whether other perinatal EFAs might be related to neonatal IgE levels. We found several associations that can only be interpreted in the light of specific hypotheses. There are currently two main hypotheses to explain the relationship between EFAs and atopy. The first hypothesis suggests that desaturation of LA and ALA into their longer chain polyenes (LCPs) is impaired in atopic subjects as a result of an impaired enzyme activity of delta-6-desaturase (the delta-6-desaturase hypothesis) $(10,24)$. This hypothesis is based observational studies that found increased levels of LA and substantially lower levels of its LCPs, such as AA, in blood (10-12), adipose tissue (11) and breast milk (13) of adults with atopic disease, when compared with healthy subjects. As regards the n-6 EFAs, we did not confirm a higher LA level in mother or neonate in relation to high neonatal IgE (in fact, the reverse was found for maternal LA). Nor did we find lower n-6 LCPs, and maternal AA was even higher in relation to high neonatal IgE. As regards the n-3 EFAs, no association was found between maternal EFAs and neonatal IgE. The associations found for neonatal n-3 EFAs showed no pattern consistent with the delta6-desaturase hypothesis.

The second hypothesis is based on the time trends in the prevalence of atopic diseases and the consumption of FAs in developed countries (38). The increased consumption of vegetable oils rich in LA and a simultaneously reduced consumption of fatty fish (rich in n-3 EFAs) has been accompanied by an increased prevalence of atopic disease $(25,26)$. In atopic infants these associations have been described $(42,43)$. It has therefore been hypothesized that the increased consumption of LA and the consequent increase in the ratio between n-6 and n-3 EFAs in the diet may have led to an increase in atopic diseases (the $n-6 / n-3$ EFA hypothesis). We found no consistently higher $n-6$ and lower n-3 EFA levels in relation with neonatal IgE. We conclude that none of the relationships we found were in agreement with any of the hypotheses on EFAs and atopy, and that none of the changes showed a consistent pattern. Nevertheless, the number of statistically significant associations between neonatal n-3 EFAs and neonatal $\mathrm{IgE}$ was higher than expected on the basis of chance and 
this topic therefore needs further research and perhaps a different hypothesis.

The definition of atopy has been modified in the last few years. In 2001, a revised nomenclature for allergy was suggested by the European Academy of Allergology and Clinical Immunology (EAACI) in a position statement (40) The general accepted definition in the preceding decades was described as follows: "Atopy is a personal or familial tendency to produce $\operatorname{IgE}$ antibodies in response to low doses of antigens, usually proteins, and to develop typical symptoms such as asthma, rhinoconjunctivitis, or eczema/dermatitis.' However, in this position statement it was acknowledged that atopy is not always associated with increased IgE levels. Therefore we have to be cautious with translating the results to atopy.

Nonetheless, neonatal IgE is thought to be a determinant of later atopy and the present results seem to contradict the known relationship between perinatal EFAs and the later development of atopy $(14,27,28)$. However, most studies used clinical atopic outcomes or composite outcomes including clinical and laboratory data; the study in infants that showed an association between cord blood EFAs and later atopy did not find an association with later $\mathrm{IgE}$ either (14). Further evidence that EFAs are not related to the IgE component of atopy was found in the present study (results presented elsewhere). We found that a relatively low perinatal n-3 LCP status in the breastfed infants was associated with greater severity of $\mathrm{AD}$ at age 1 year, but not with total serum IgE at that age (van Gool C.J.A.W., Thijs C., van Houwelingen A.C., Henquet C.J.M., Dagnelie P.C., Schrander J., Menheere P.P.C.A., van den Brandt P.A., unpublished data). In a supplementation study with GLA we found that the increase in plasma GLA during supplementation was associated with lower severity of AD, but again not with total serum IgE (34). We conclude that the effect of perinatal EFAs on the later development of atopic disease must be independent of the neonatal production of $\operatorname{IgE}$ and is not likely to be influenced by parity.

Karmaus and Botezan provided several hypothetical explanations for the possible in utero effects of parity on total serum IgE levels in cord blood (29) and summarized these explanations as the 'in utero programming disruption hypothesis'. Changes in hormones, maternal immune suppression to prevent rejection of the fetus, maternal infections during pregnancy and lifestyle characteristics such as smoking might all influence the environment of the unborn child. One of two North-European studies found blood IgE levels to be associated with parental smoking during pregnancy (30), whereas the other found an association with maternal caffeine and alcohol use (31).

A large German study showed no association between birth season and cord blood IgE, and two NorthEuropean studies were contradictory, one showing peaks in late autumn (31) whereas the other showed the lowest cord blood values in autumn (32). Another North-
European study found that exposure of the mother during pregnancy to high levels of birch pollen resulted in a tendency toward an increased risk of sensitization to the same allergen in infants at risk of atopy (41). A Dutch study showed an increased relative risk for children born up to 3 months before the main pollen season, together with an increased relative risk for cat, dog, egg white and cow's milk allergens from November to January (35). These results are consistent with our findings. We know of no previous studies that have reported on the seasonality of both maternal and neonatal $\mathrm{IgE}$. Our finding of higher maternal IgE levels in spring is consistent with pollen allergy. To match this with our finding of lowest neonatal IgE values in the first 3 months of the year, it is important to recognize that the fetal ability to produce IgE does not start before the second trimester (33). Our finding of lowest neonatal IgE values in the first 3 months of the year is consistent with second and third trimester pregnancy outside the pollen season. Therefore, our findings might suggest that pollen exposure in pregnant women with a personal history of atopy confers intrauterine stimulation of fetal IgE production. In a review of intrauterine influences on atopy, Jones concluded that allergens but not $\mathrm{IgE}$ are transferred through the placenta, and proposed that IgE is amniotically transferred and ingested by the fetus, and is later counterbalanced by transplacental IgG (33). If neonatal IgE originated directly from the mother, it would show a peak simultaneously with that of the mother, which it did not in our study. Therefore, possible explanations include fetal production of IgE stimulated by maternally transferred pollen allergens, transamniotic IgE transfer or unknown maternal immunologic stimuli related to seasonal allergy. However, because of multiple comparisons in the analyses and because of inconsistent results in previous studies we are very cautious in drawing definite conclusions about seasonality. In our study maternal total IgE seemed to decrease with parity (Table 1), but this was not statistically significant in the regression analysis (Table 2). In spite of this, it may still be a confounder of the relationship between parity and neonatal IgE. The multivariate regression analysis in Table 2 controlled for this confounder.

The present study confirms the conclusions of earlier studies: parity has a negative influence on the DHA status in pregnant mothers and is also related to total serum IgE in neonates at the age of 1 week. However, our results show that the effect is independent of changes in EFA status.

\section{Acknowledgments}

The authors would like to thank all midwives, parents and neonates for participating; Manon Meijs, Alice Fleuren, Annemie Mordant, Diane Crook, Hasibe Aydeniz, Nancy Hendrix, Janny de Vrieze and Steven Stapel provided valuable and enthusiastic assistance. 


\section{Determinants of neonatal IgE level}

\section{References}

1. Williams HC. Is the prevalence of atopic dermatitis increasing? Clin Exp Dermatol 1992;17:385-391.

2. StRaChan DP. Hay fever, hygiene, and household size. Br Med J 1989;299:1259-1260.

3. von Mutius E, MarTinez FD, Fritzsch C, Nicolai T, RetTmeir P, ThiemanN HH. Skin test reactivity and number of siblings. Br Med J 1994;308:692-695.

4. Matricardi PM, Rosmini F, Ferrigno L, NisinI R, Rapicetta M, Chionne P et al. Cross sectional retrospective study of prevalence of atopy among Italian military students with antibodies against hepatitis A virus. Br Med J 1997; 314:999-1003.

5. STRACHAN DP. Family size, infection and atopy: the first decade of the 'hygiene hypothesis'. Thorax 2000;55: S2-S10.

6. Karmaus W, Arshad H, Mattes J. Does the sibling effect have its origin in utero? Investigating birth order, cord blood immunoglobulin E concentration, and allergic sensitization at age 4 years. Am J Epidemiol 2001;154:909-915.

7. Martinez FD, Wright AL, Taussig LM, Holberg CJ, Halonen M, MorGAN WJ. Asthma and wheezing in the first six years of life. The Group Health Medical Associates. N Engl J Med 1995;332:133-138.

8. Chandra RK, Puri S, Cheema PS. Predictive value of cord blood IgE in the development of atopic disease and role of breast-feeding in its prevention. Clin Allergy 1985;15:517-522.

9. Brown WR, HANSEN AE. Arachidonic and linolic acid of the serum in normal and eczematous human subjects. Proc Soc Exp Biol Med 1937;36:113-117.

10. MANKU MS, Horrobin DF, Morse N, KYte V, Jenkins K, Wright $S$ et al. Reduced levels of prostaglandin precursors in the blood of atopic patients: defective delta-6-desaturase function as a biochemical basis for atopy. Prostaglandins Leukotrienes Med 1982;9:615-628.

11. Wright S, SANDers TA. Adipose tissue essential fatty acid composition in patients with atopic eczema. Eur J Clin Nutr 1991;45:501-505.

12. LiNDSKov R, Holmer G. Polyunsaturated fatty acids in plasma, red blood cells and mononuclear cell phospholipids of patients with atopic dermatitis. Allergy 1992;47:517-521.
13. Thus C, van Hounelingen AC, Poorterman I, Mordant A, van den BRANDT P. Essential fatty acids in breast milk of atopic mothers: comparison with non-atopic mothers, and effect of borage oil supplementation. Eur J Clin Nutr 2000;54:234-238.

14. Galli E, Picardo M, Chini L, Passi S Moschese V, Terminali $O$ et al. Analysis of polyunsaturated fatty acids in newborn sera: a screening tool for atopic disease? Br J Dermatol 1994;130: 752-756.

15. Al MD, van Houwelingen AC, Kester AD, Hasaart TH, de Jong AE, HornSTRA G. Maternal essential fatty acid patterns during normal pregnancy and their relationship to the neonatal essential fatty acid status. Br J Nutr 1995;74:55-68.

16. Al MD, van Houwelingen AC, HoRNSTRA G. Relation between birth order and the maternal and neonatal docosahexaenoic acid status. Eur J Clin Nutr 1997;51:548-553.

17. Otto SJ, Foreman van Drongelen MM, VAN HouWELINGEN AC, HorNSTRa $G$. Effects of storage on venous and capillary blood samples: the influence of deferoxamine and butylated hydroxytoluene on the fatty acid alterations in red blood cell phospholipids. Eur J Clin Chem Clin Biochem 1997;35:907-913.

18. Kaluzny MA, Duncan la, Merritt MV, EPps DE. Rapid separation of lipid classes in high yield and purity using bonded phase columns. J Lipid Res 1985;26:135-140.

19. Paganelli R, Ansotegui IJ, Sastre J, LANGe CE, Roovers MH, DE Groot H et al. Specific IgE antibodies in the diagnosis of atopic disease. Clinical evaluation of a new in vitro test system, UniCAP, in six European allergy clinics. Allergy 1998;53:763-768.

20. Aalberse RC, Brummelhuis HG, REERINK BRONGERS EE. The purification of human polyclonal IgE by immunosorption. Immunochemistry 1973;10: 295-303.

21. Kleinbaum DG, Kupper ll, Muller KE, Nizam A. Applied regression analysis and other multivariable methods Pacific Grove: Duxbury Press, 1998.
22. InNIS SM, SPReCher H, Hachey D, EdMOND J, ANDERSON RE. Neonatal polyunsaturated fatty acid metabolism. Lipids 1999;34:139-149.

23. HoRnSTRA G. Essential fatty acids in mothers and their neonates. Am J Clin Nutr 2000;71:1262s-1269s

24. Horrobin DF. Nutritional and medical importance of gamma-linolenic acid. Prog Lipid Res 1992;31:163-194.

25. BLACK PN, Sharpe S. Dietary fat and asthma: is there a connection? Eur Respir J 1997;10:6-12.

26. Kankaanpaa P, Sutas Y, Salminen S, LiCHTENSTEIN A, ISOLAURI E. Dietary fatty acids and allergy. Ann Med 1999;31:282-287.

27. Wright S, Bolton C. Breast milk fatty acids in mothers of children with atopic eczema. Br J Nutr 1989;62:693-697.

28. Businco L, IopPI M, Morse NL, NisinI R, WRIGHT S. Breast milk from mothers of children with newly developed atopic eczema has low levels of long chain polyunsaturated fatty acids. J Allergy Clin Immunol 1993;91:1134-1139.

29. Karmaus W, Botezan C. Does a higher number of siblings protect against the development of allergy and asthma? A review. J Epidemiol Community Health 2002;56:209-217.

30. Bergmann RL, Schulz J, Gunther $S$, Dudenhausen JW, Bergmann KE, BaUER CP et al. Determinants of cord-blood IgE concentrations in 6401 German neonates. Allergy 1995;50: 65-71.

31. BJerke T, HedegaArd M, Henriksen TB, Nielsen BW, SChIOTZ PO. Several genetic and environmental factors influence cord blood IgE concentration. Pediatr Allergy Immunol 1994;5:88-94.

32. Hansen lG, Host A, Halken S, Holmskov A, HusBy S, LASSEN LB et al.. Cord blood IgE. I. IgE screening in 2814 newborn children. Allergy 1992;47:391-396.

33. Jones CA, Holloway JA, Warner Jo Does atopic disease start in foetal life? Allergy 2000;55:2-10.

34. van Gool CJ, Thiss $\mathrm{C}$, Henouet CJ, van Houwelingen AC, Dagnelie PC, SCHRANDER J et al. Gamma-linolenic acid supplementation for prophylaxis of atopic dermatitis - a randomized controlled trial in infants at high familial risk. Am J Clin Nutr 2003;77:943-951.

35. Aalberse RC, Nieuwenhuys EJ, Hey M, Stapel SO. 'Horoscope effect' not only for seasonal but also for nonseasonal allergens. Clin Exp Allergy 1992;22:1003-1006 
van Gool et al.

36. Edenharter G, Bergmann RL, Bergmann KE, Wahin V, Forster J, ZEPP $F$ et al. Cord blood-IgE as risk factor and predictor for atopic diseases. Clin Exp Allergy 1998;28:671-678.

37. HALKEN S. Early sensitisation and development of allergic airway disease risk factors and predictors. Paediatr Respir Rev 2003;4:128-134.

38. CALDER PC. Polyunsaturated fatty acids and cytokine profiles: a clue to the changing prevalence of atopy? Clin Exp Allergy 2003;33:412-415.
39. KankaAnpaA P, Nurmela K, Erkkila A, Kalliomaki M, HolmberGMartilla D, Salminen S et al. Polyunsaturated fatty acids in maternal diet, breast milk, and serum lipid fatty acids of infants in relation to atopy. Allergy 2001;56: 633-638.

40. Ohansson SG, Hourihane Jo, Bousquet J, Bruunzeel-Koomen C, Dreborg $S$, Hahertela $T$ et al. A revised nomenclature for allergy. An EAACI position statement from the EAACI nomenclature task force. Allergy 2001;56:813-824.
41. Kihlstrom A, Lilja G, Pershagen G, HedLin G. Exposure to high doses of birch pollen during pregnancy, and risk of sensitization and atopic disease in the child. Allergy 2003;58:871-877.

42. Duchen K, Bjorksten B. Polyunsaturated $n-3$ fatty acids and the development of atopic disease. Lipids 2001;36:1033-1042.

43. YU G, BJoRKSTEN B. Serum levels of phospholipid fatty acids in mothers and their babies in relation to allergic disease. Eur J Pediatr 1998;157:298-303. 